\title{
In the Train with Mr. Madden
}

\section{Samuel Beckett}

I trust an only child, I was born at $\mathrm{P}-$. My parents came from $\mathrm{Q}-$. From them it was I received, together with the pale treponema, the huge nose whose remains you have before you. They were severe with me, but just. For the least peccadillo my father beat me till I bled, with his solid razor-strop. But he never failed to notify my mother so that she might dress my wounds, with tincture of iodine or permanganate of potash. Here lies no doubt the explanation of my unconfiding character and general surliness. Unfitted for the pursuit of knowledge I was taken away from school and placed with farmers near by. Heaven, as they put it, having denied them offspring, they fell back on me with very natural virulence. And when my parents perished, in a providential railway smash, they adopted me with all the forms and observances required by the law. But no less feeble of body than of mind I was for them a constant source of disappointment. To follow the plough, ply the scythe, flounder in the mangels, and so on, were labours so far beyond my strength that I literally collapsed whenever forced to undertake them. Even as shepherd, cowherd, goatherd, pigherd, it was in vain I exerted myself to the utmost, I could never give satisfaction. For the animals strayed, unnoticed by me, into the neighbouring properties and there ate their bellyful of flowers, fruit and vegetables. I pass over in silence the combats between rutting males, when I fled in terror to take refuge in the nearest barn. Add to this that the flock or herd, because of my inability to count beyond ten, seldom came home at full muster, and with this I was deservedly reproached. The only branches in which I may boast of having, if not excelled, at least succeeded, were the slaughter of little lambs, calves, kids and piggy-wiggies and the emasculation of little bullocks, rams, billy goats and porklings, on condition of course they were still unspoilt, all innocence and trustingness. It was therefore to these specialities I confined myself, from the age of fifteen. I have still at home some charming little-well, comparatively little-ram's testicles dating from that happy time. In the poultry-yard too I was a terror of precision and elegance. I had a way of smothering geese that was the envy and admiration of 
all. Oh I know you are listening with only half an ear, and that half unwilling, but that is nothing to me. For I am old and the only pleasure I have left is to recall, out loud in the noble style I loathe, the good old days happily gone for ever. At the age of twenty, or possibly nineteen, having been awkward enough to fecundate a milkmaid, I ran away under cover of night, for I was closely watched. I improved this occasion by setting fire to the barns, granaries and stables. But these conflagrations were scarcely under way when they were doused by a downfall none could have foreseen, so starry was the sky at the moment of the deed. Rain is the curse of this misfortunate country. That was fifty years ago, feels like five hundred. He brandished his stick and brought it down with a thump on the seat which emitted instantaneously a cloud of fine ephemeral dust. Five hundred! he bellowed.

The train slowed down. Mercier and Camier exchanged a look. The train stopped.

Woe is us, said Mercier, we're in the slow and easy.

All the better perhaps, said Camier.

No perhaps about it, said the old man.

We could have got down, said Mercier, now it is too late.

You can get down with me, said the old man, at the next stop.

That puts a new face on us, said Mercier.

Butcher's boy, said the old man, poulterer's boy, knacker's boy, undertaker's man, sexton, one corpse on top of another, there's my life for you. Gab was my salvation, every day a little more, a little better. The truth is I had that too in my bleeding blood, my father having sprung, with what alacrity you may imagine, from the loins of a parish priest, it was common knowledge. I infested the outlying whoreshops and saloons. Comrades, I said, having never learnt to write, comrades, Homer tells us, Iliad Book 3 lines 85 and following, in what consists happiness here below, that is to say happiness. Oh I gave it to them! Potopompos scroton evohe! Like that, hot and strong! Picked up at nightschool -he burst into a wild raucous laugh-free nightschool for glimmer-thirsty wrecks. Potopompos scroton evohe, the soft cock and buckets of the hard. Step out of here, I said, with a stout heart and your bollocks in your boots and come again tomorrow, tell the old woman to go chase apes in hell. There were delicate moments. Then up I'd get, covered with blood and my rags in ribbons, and at 'em again. Brats the offscourings of fornication and God Almighty a cheap scent in a jakes. But they bore with me in the end. I cleaned myself up and crashed their weddings, funerals, balls, wakes and christenings. They made me welcome, another ten years and I'd be popular. I let them have it on the lot, hymen, vaseline, the evil day from dawn to dusk. One corpse on top of another, there's my life for you. Until I came in for the farm, or perhaps I should say the farms, for there were two. The creatures, bless their hearts, they loved me to the end. A good thing for me they did, for my snout was beginning to crumble. People love you less when your snout begins to crumble. Here we are.

Mercier and Camier drew in their legs to let him pass. 
You're not getting down? said the old man. You're right, only the damned get down here.

He wore gaiters, a yellow block-hat and a kind of frock-coat reaching down to his knees. He lowered himself stiffly to the platform, turned, slammed the door and raised to them his hideous face.

Yes, he said, that's the way with me, I pick my carriage, wait till the train starts to move, then hop on. They think they have it to themselves, no danger of intruders, but not so fast, here comes old Madden at the last, the train gets under way, they are pent up with old Madden, nothing to be done.

The train moved on again.

Adieu adieu, cried Mr. Madden, they loved me to the end, they loved -.

Mercier, who had his back to the engine, saw him as he stood there, dead to the passengers hastening towards the exit, bow down his head till it lay on his hands at rest on the knob of his stick.

(Extract from Mercier et Camier translated by the author.) 